\title{
SCENARIO MODELING EXPLOITATION DECISION-MAKING PROCESS IN TECHNICAL NETWORK SYSTEMS
}

\section{SCENARIUSZOWE MODELOWANIE EKSPLOATACYJNEGO PROCESU DECYZYJNEGO W SIECIOWYCH SYSTEMACH TECHNICZNYCH*}

\begin{abstract}
The article shall discuss on the use of methods of modeling future variants, including scenarios, for assessment and shaping the decision-making process relating to exploitation of technical systems. The analysis showed a strong need the exploiters for influencing the decision-making process in long-term. In view of the above assumptions, and based on the results of the research, there was developed a procedure for building exploitation scenarios models, which was then verified in the context of functioning of the technical network system - water supply system.
\end{abstract}

Keywords: decision-making process, scenario methods, exploitation policy, techncal network systems, maintenance management.

\begin{abstract}
Artykut podejmuje dyskusję nad wykorzystaniem metod modelowania wariantów przyszłości, w tym scenariuszy, dla potrzeb oceny i ksztaltowania procesu decyzyjnego dotyczacego eksploatacji w systemach technicznych. Przeprowadzona analiza wykazała duża potrzebe eksploatatorów do wptywania na proces decyzyjny $w$ aspekcie dlugoterminowym. W świetle powyższych zatożen, a także w oparciu o wyniki dotychczasowych badań, opracowano procedurę budowy modeli scenariuszy eksploatacyjnych, która następnie zweryfikowano w kontekśsie funkcjonowania wybranego sieciowego systemu technicznego - systemu wodociagowego.
\end{abstract}

Stowa kluczowe: proces decyzyjny, metody scenariuszowe, polityka eksploatacyjna, sieciowe systemy techniczne, zarządzanie eksploatacja.

\section{Introduction}

Exploitation future is closely linked to the past and present, assuming the shape of complex interactions between: decisions, and consequently the operating and maintenance activities, which are realized in the present, and the effects and/or consequences occurring in the future. In other words, an insight into exploitation future is possible by recognizing current events. The key problem seems to be the possibility of shaping the decision-making process, which, in this article, will be defined as the exploitation decision-making process. Such a process focuses effects of modeling exploitation policy, being the subject of its assessment, both internally - against functioning of the technical network system, and externally - in terms of requirements and conditions of the environment of the maintenance organization.

Every decision concerning the future behavior of technical objects is charged with some uncertainty, which in this approach is reflected in the volume and variety of possible paths of exploitation procedures to choose (operating and maintenance) [14]. This uncertainty is further increased by the long-time horizon of the intended effects or consequences of decision making. In this context, there are important the answers to the following practical questions [4, 22]:

1. How long will the technical object/system fulfill its functions at a given level of the performance/effectiveness?

2. When will occur a need to replace the technical object/system, in order to use the exploitation potential in an optimal way, assuming cost minimization criteria?

3. What decisions should be taken today to ensure maximum exploitation potential of the technical object/system in the future?

The answers to these questions are possible on the basis of developed, in quantitative way, models of exploitation processes, including variability of the features of the analyzed technical object/system, as well as dynamic environmental conditions, in which it operates. It is also important reliable assessment of the future results of present activities, in particular, quantitative analysis of possible problems and potential effects or consequences of decisions taken $[1,3,10$, 17, 20].

For the purpose of shaping the exploitation decision-making process, there can be useful concepts and methods for modeling and analysing future variants. They enable the use of multi-threaded image of the current reality, with simultaneous possible look, which is far ahead of the current time. It results in scenarios of future behaviors of technical objects and guidelines for functioning technical staffs within the maintenance departments of the enterprises.

In response to the above formulated circumstances, later in this article, there was developed and presented the way of scenario modeling and assessment of the exploitation decision-making process.

2. Review of the concepts of modeling future variants in the context of shaping the exploitation decisionmaking process

Modeling the future variants is related to the preparation of assumptions and images, for identifying the development of events, which may occur in the period which may occur in the period much ahead of the current moment. This is to the optimal realization of the decision making process, by tracking its possible future effects or consequences.

In the studies on methods of modeling future variants, which are carried out since the fifties of the twentieth century $[12,35]$, initially there were distinguished two opposing general concepts. According to them, future operation of a technical object can be based on predict-

$\left(^{*}\right)$ Tekst artykułu w polskiej wersji językowej dostępny w elektronicznym wydaniu kwartalnika na stronie www.ein.org.pl 
ing, which results in the prediction, or on the anticipation, the efect of which is a vision. In particular [24, 34, 37]:

- prediction is the effect of the mathematical modeling and is a quantitative - computation,

- vision is due to search for goals and values of the future, in the form of immeasurable interrelated descriptions, facts and statements; valid vision is simple and understandable, but not entirely quantified.

The specificity of the exploitation decision-making process realized in an industrial environment, which is based on the quantitative characteristics and the features expressed in the descriptive form, justifies the need to link the quantitative character of predictions with the qualitative and descriptive character of visions. A tool, that meets these requirements is a scenario, which in this case, can fill the gap between the aforementioned concepts, being their common part.

In the area of research, as well as in the context of practical applications, scenario is defined inconsistently. It results from its interpretation in the aspect of the purpose and scope of the specific project of modeling of future variants. These definitions can be summarized in two categories:

- scenario in the methodological term, as a way of dealing with the decision uncertainty, on the basis of an internally consistent image of the future, represented by a set of descriptions of possible variants of future events or situations [9, 33],

- scenario in the utility term, as a response to the results of research and application, as a set of methods and tools, enabling optimization of the decision-making process within the issues of strategic management $[18,32,36]$.

The scenario is a tool that helps to present the future and allows us to answer the questions:

- what conceivable can happen, when ...? or

- what could happen, when ...?

Development and effective use of scenarios within the exploitation decision-making process, requires reaching to the concept of the prediction and the vision. Prediction is short-term and allows you to determine the potential change of the technical conditions of the object, which facilitates the formulation of decisions and the realization of activities [5]. With the increase of the distance of time in the future, there are required methods and tools to assess the possibilities and risk of potential decisions relating to the exploited object, as well as its economic and organizational environment [2]. This enables to prepare on not one, but more future images. This can be demonstrated using the futures funnel concepts (Fig. 1). It displays the multiplicity and

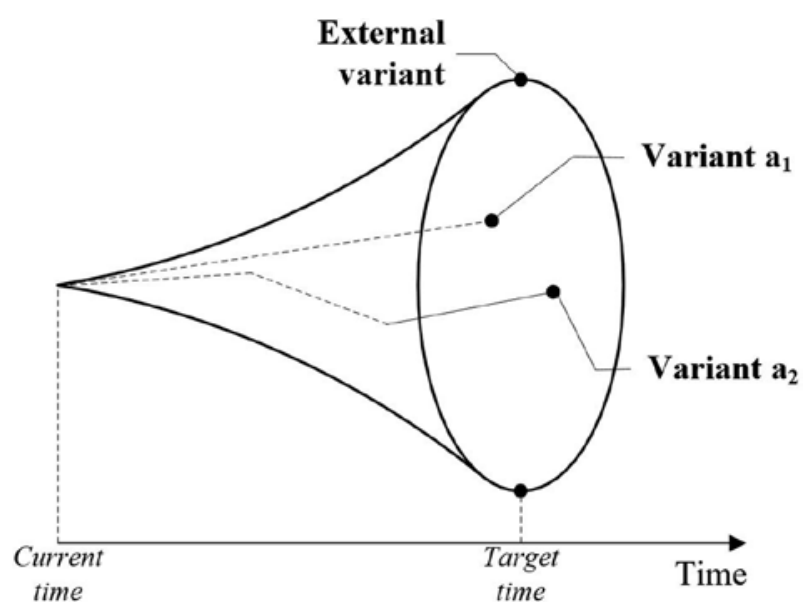

Fig. 1. The graphical interpretation of the concept of the so-called funnel of future variants diversity of possible courses to achieve alternative results describing the effects/consequences of the decisions taken.

On the input of scenario process, there should be a clear set of information defining the main goals of the entire project. The output from the scenario project can indicate to the consequences (variants) of potential occurrence of events and circumstances, described by scenarios, in a simple and understandable way for users.

The results of the research on possibilities and needs of the use of methods of modeling future variants (including scenario methods), in shaping of the exploitation decision-making process, revealed that:

1. Scenario methods of modeling future variants, although known and used in the macro area - global strategic planning [7, 11, $27,32,33]$, not yet gained greater recognition in the micro area - the operation of individual systems under technical and organizational conditions.

2. The issue of the use of scenario methods of modeling future variants, appears in the bibliography incidentally in the context of solving exploitation problems. There are single descriptions of the practical applications of scenarios in the emergency tasks [16], or in acquiring diagnostic knowledge of the selected group of machines [26].

3. Domestic and foreign publications and other elaborations include the references to the selected methods and partial issues used in complex solution, proposed in this article [18, 22, 28, 32].

4. The use of scenario methods for the needs of complex modeling of the exploitation decision-making process can be considered a new issue, not published in Poland and abroad.

5. Proposed methodology and application solutions (tools), can fill the gap in shaping the exploitation decision-making process of industrial enterprises.

\section{Methodology of scenario modeling of the exploita- tion decision-making process}

The analysis of the possibilities of the future variants description, justifies the need to develop a methodology for modeling the exploitation decision-making process with the use of scenario methods.

The realization of the undertaken research tasks was to develop scenario models with the use of selected methods and tools, and then to assess their suitability within the framework of supporting the longterm exploitation decision-making process. The content of the developed models and the basis of their quantitative verification was a set of data obtained from the activities of the maintenance organization of the company managing the network technical system - the water supply system.

Firstly, there was developed procedure for constructing models of the exploitation scenarios (Fig. 2), which:

- was coherent to the general scenario logic represented by three key concepts: the intuitive logic concept [18, 34], La Prospective concept $[8,9,32]$, TIA/CIA concept (Trend Impact Analysis/Cross Impact Analysis) [6],

- was adequate for the considered problem of the identification and description of the future images for development of the exploitation policy of the analyzed water supply system [13, 19].

The A phase of the scenario procedure, first focus on the identification of a set of factors, describing the impact of the external and internal environment on the exploitation policy, in a way that underlines aspects of convergent and consistent with the considered issues of decision-making. For this purpose, STEEPVL model was applied $[27,34]$. It provided the basis for structuring factors under the seven categories: Social, Technological, Economic, Ecological, Political, Value, Legal. The second stage of the A phase was to specify the main scenario problem. The main scenario problem is expressed in the form 


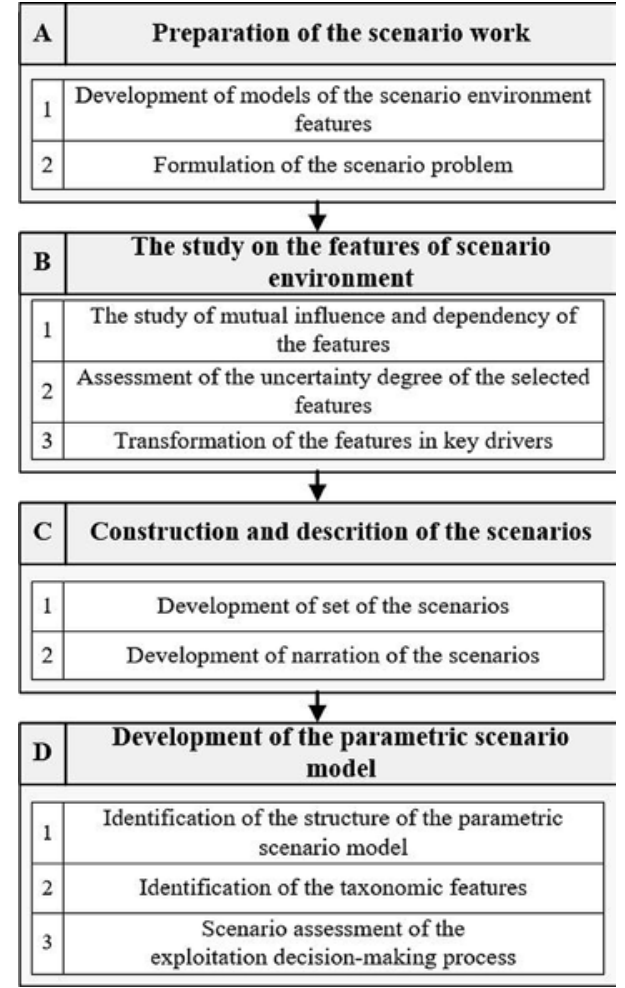

Fig. 2. The procedure for constructing scenario models of the development of the exploitation policy

of the so-called focal question and is the target, to which are referred potential effects/consequences of the scenario procedure.

The $\mathrm{B}$ phase of the scenario procedure was to extract key factors, which, such that, on the one hand, they were the most important for the formulated main problem, and on the other they had the highest degree of uncertainty, in relation to the target time point. To do this, there were identified the level of mutual interactions between key factors, by determining the number of tracks and loops of nodes, built on the basis of the prepared matrix of impacts and relationships (direct and indirect) between the factors. For the needs of carrying out this task, there was used the structural analysis method [7, 18, 28], which is schematically shown in Fig. 3.
In order to distinguish the factors as a basis of the scenarios construction, there was proposed the procedure of parametric comparison of the key factors, in the context of the mutual interactions and the level of uncertainty. The result of this comparison, for three key factors, was described by the matrix expressing the summary mutual level of the scenario advantage:

$$
T_{i}=\left[\begin{array}{ccc}
\ldots & c_{12} & c_{13} \\
c_{21} & \ldots & c_{23} \\
c_{31} & c_{32} & \ldots
\end{array}\right]
$$

where: $c_{i j}$ - the assessment of the advantage of the impact/uncertainty of $i$ factor over $\mathrm{j}$ factor.

The possible values of the assessment of the advantage of the impact/uncertainty of $\mathrm{i}$ factor over $\mathrm{j}$ factor $\left(c_{i j}\right)$ are shown in Table 1.

The final result of the B phase was the set of key factors ordered using the procedure of the parametric assessment of the mutual scenario advantage.

The $\mathrm{C}$ phase of the scenario procedure was to develop the scenario models. For this purpose, the identification of a predetermined number of scenarios was performed (usually four), on the basis of a relationship between two or three key factors, as defined in the B phase of the scenario procedure (Fig. 4).

There was proposed the use of three forms of the scenario description as the next steps of their detailing:

- symbolic description, as an ordered set of agreed values of factors, assigned to the scenarios,

- schematic description, as an ordered set of statements, which was syntactic development of a symbolic description for the scenarios,

- narrative description, as an ordered set of content, which was a semantic extend of the schematic description for the scenarios.

Table 1. The set of possible values for the assessment of the advantage of the impact/uncertainty of $i$ factor over $j$ factor (cij)

\begin{tabular}{||c|l||}
\hline \hline Values $\boldsymbol{c}_{\boldsymbol{i} j}$ & \multicolumn{1}{c|}{ Interpretation of cij values } \\
\hline 1 & impact/uncertainty of $i$ factor, greater than impact/uncertainty of $j$ factor \\
\hline 0,5 & impact/uncertainty of $i$ factor, equal to impact/uncertainty of $j$ factor \\
\hline 0 & impact/uncertainty of $i$ factor, lower than impact/uncertainty of $j$ factor \\
\hline \hline
\end{tabular}

Matrix of impacts and relationships

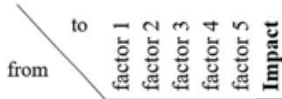

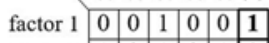

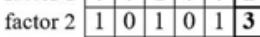

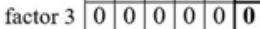

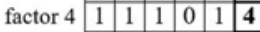

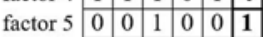

Relationship \begin{tabular}{|l|l|l|l|l|}
\hline & $\mathbf{1}$ & $\mathbf{4}$ & $\mathbf{0}$ & $\mathbf{2}$ \\
\hline
\end{tabular}

\section{Map of impacts and relationships}
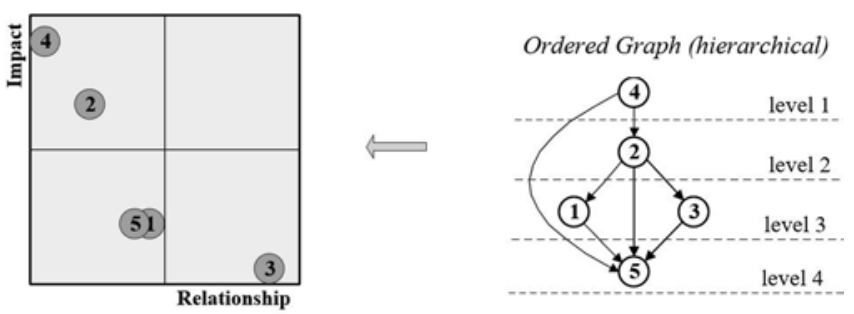

Fig. 3. The concept of the structural analysis, based on La Prospective methodology [8, 28]

\section{Disordered graph}

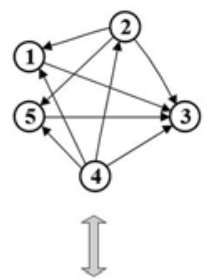

Ordered Graph (hierarchical)
Fig. 4. The modeled layout of four scenarios [18, 32]

The D phase of the scenario procedure was to develop a parametric scenario model. It was a quantitative interpretation of the symbolic model and the schematic model, enabling the assessment of the compliance level of the exploitation policy with the developed scenarios. 
Table 2. A generalized set of input components to the parametric model for the assessment of the exploitation scenarios

\begin{tabular}{|c|c|c|c|c|c|}
\hline \multicolumn{6}{|c|}{ Scenario $S$} \\
\hline & & Factor 1 & $\ldots$ & & Factor $m$ \\
\hline Weight & & $w_{1}$ & $\ldots$ & & $w_{m}$ \\
\hline Feature 1 & & $c h_{11}$ & $\ldots$ & & $c h_{1 m}$ \\
\hline$\ldots$ & & $\ldots$ & $\ldots$ & & $\ldots$ \\
\hline Feature $n$ & & $c h_{n 1}$ & $\ldots$ & & $c h_{n m}$ \\
\hline Category 1 & $k t_{11}$ & $w k t_{11}=\frac{k t_{11}}{\sum_{i=1}^{p} k t_{i 1}}$ & $\ldots$ & $k t_{1 n}$ & $w k t_{1 m}=\frac{k t_{1 m}}{\sum_{i=1}^{p} k t_{i m}}$ \\
\hline Category $p$ & $k t_{p 1}$ & $w k t_{p m}=\frac{k t_{m n}}{\sum_{i=1}^{p} k t_{i m}}$ & $\ldots$ & $k t_{n n}$ & $w k t_{p m}=\frac{k t_{m n}}{\sum_{i=1}^{p} k t_{i m}}$ \\
\hline
\end{tabular}

Development of the parametric scenario models began with the transformation of the symbolic and the schematic representation in the description representation. This consisted in the interpretation and transformation of the symbols and statements at the set weights and then ordering them (Table 2).

where: $\mathrm{w}_{\mathrm{i}}$ - weights of the key factors, whose values were determined in the $\mathrm{B}$ phase of the scenario procedure, $\mathrm{ch}_{\mathrm{ij}}$ - weights of the key features of the exploitation policy (cost, time, quantity of exploitation tasks completed in a reference period [21]), whose values from the range $(0,1)$ describe the level of significance of the features against the scenario key factors, as a result of the assessment carried out by a scenario team in response to the question: What is the level of the key features in view/against a particular value of a scenario key factor?, $\mathrm{kt}_{\mathrm{ik}}$ - weights of the categories of the maintenance works (inspections, maintenances, repairs, overhauls), whose values from the range $(0,1)$ describe the level of importance of each category against the individual key factors, as a result of the assessment carried out by a scenario team in response to the question: What is the level of a maintenance category in view/ against a particular value of a scenario key factor?

Determination of the coefficients, as the basis for identifying the maintenance works structure against the key features, required a synthesis of various weight groups within a coherent and representative model. For the purposes of such synthesis, there was used a hierarchical model of objectives decomposition, which is a component of the method of the concepts valuation [30]. In this respect, the components tree was defined, obtaining the hierarchical weight structure (Fig. 5).

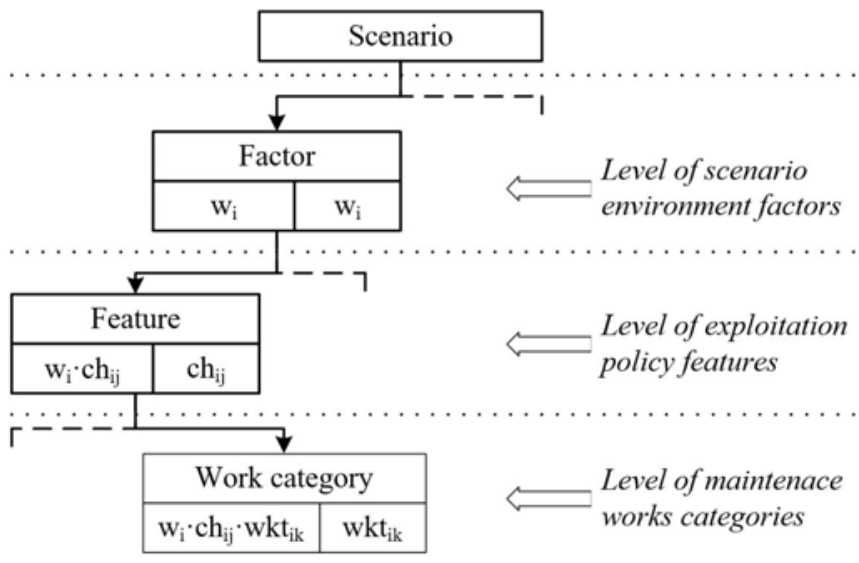

Fig. 5. The generalized form of the components tree for the parametric model of the assessment of the exploitation scenarios
The tree shown in Fig. 5, combines the weights hierarchically, in such a way, that the absolute values of the components (determined with reference to the highest level) are the product of the relative values of all the previous levels within a given path. The result of so constructed tree are the synthetic values of coefficients, necessary to determine the quantitative structure of the maintenance works, in the context of the key features of the exploitation policy. The values of coefficients (based upon the shape and content of the tree) are determined according to the (6).

$$
R_{j k}=\left(\sum_{i=1}^{m} w_{i} \cdot c h_{i j} \cdot w k t_{i k}\right) \cdot P w_{j}
$$

where: $R_{j k}$ - the value of $\mathrm{j}$-th key feature of the exploitation policy for k-th category of the maintenance works, $w_{i}$ the weight of the i-th scenario environment factor, $c h_{i j}$ - the weight of the j-th key feature in the context of the i-th sce-

Table 3. The generalized set of components for the parametric model of the exploitation policy assessment

\begin{tabular}{||l|c|c|c||}
\hline \hline \multicolumn{4}{|c|}{ Scenario $\mathbf{~}$} \\
\hline & Key feature 1 & $\ldots$ & Key feature $\mathrm{n}$ \\
\hline Category 1 & $\mathrm{R} 11$ & $\ldots$ & $\mathrm{R} 1 \mathrm{n}$ \\
\hline$\ldots$ & $\ldots$ & $\ldots$ & $\ldots$ \\
\hline Category $\mathrm{p}$ & $\mathrm{Rp} 1$ & $\ldots$ & Rpn \\
\hline \hline
\end{tabular}

nario environment factor, $w k t_{i k}$ - the weight of $k$-th category of the maintenance works in the context of the i-th scenario environment factor, $P w_{j}$ - the value of pattern parameter of $\mathrm{j}$-th key features.

General form of the parametric structure of the maintenance works, in the context of the particular key features of the exploitation policy, was shown in Table 3 .

Table 3. The generalized set of components for the parametric model of the exploitation policy assessment

\begin{tabular}{|l|c|c|c|}
\hline \multicolumn{4}{|c|}{ Scenario $\mathbf{~}$} \\
\hline & Key feature 1 & $\ldots$ & Key feature $n$ \\
\hline Category 1 & $\mathrm{R}_{11}$ & $\ldots$ & $\mathrm{R}_{1 n}$ \\
\hline$\ldots$ & $\ldots$ & $\ldots$ & $\ldots$ \\
\hline Category $p$ & $\mathrm{R}_{p 1}$ & $\ldots$ & $\mathrm{R}_{p n}$ \\
\hline
\end{tabular}

Developed quantitative structure of the maintenance works, was the foundation for the identification of the values of the taxonomic measures, which, in consequence, were used in the variant assessment of the exploitation decision-making process., In [21, 23] there was presented, elaborated by the author, the detailed procedure for determination of the taxonomic measures of the exploitation policy assessment, on the basis of purposely selected methods and tools [25, $31]$. In this regard, there were determined synthetic measures and geometric distance values of the key features of the exploitation policy for particular categories of the maintenance works, by:

- normalization of the features based on the standardization procedure:

$$
z_{i j}=\frac{c h_{i j}-\overline{c h_{j}}}{S\left(c h_{j}\right)}
$$


where: $\mathrm{z}_{\mathrm{ij}}$ - the normalized feature, $\overline{c h_{j}}$ - the average value of the class of the exploitation policy features, $\mathrm{S}\left(\mathrm{ch}_{\mathrm{j}}\right)$ - the standard deviation of the class of the exploitation policy features.

- determination of the geometric distance from the particular categories of the maintenance works to the pattern object, based on the Euclidean measure:

$$
d_{i 0}=\sqrt{\sum_{j=1}^{m}\left(z_{i j}-z_{0 j}\right)^{2}}
$$

- determination of the synthetic measures for the particular categories of the maintenance works:

$$
s_{i}=1-\frac{d_{i 0}}{d_{0}}
$$

where:

$$
z_{0 j}=\frac{\overline{z_{j}}}{S_{j}}
$$

$d_{0}=\overline{d_{0}}+2 \cdot S\left(d_{0}\right), \overline{d_{0}}=\frac{1}{n} \cdot \sum_{i=1}^{n} d_{i 0}, \mathrm{~S}\left(d_{0}\right)=\sqrt{\frac{1}{n} \cdot \sum_{i=1}^{n}\left(d_{i 0}-\overline{d_{0}}\right)^{2}}$

Determined characteristics describe the taxonomic level of distance of the maintenance works categories from the pattern [23]. This is the basis for the assessment of their contribution within the exploitation policy.

4. The exploitation scenario models of the analyzed technical network system

The developed methodology of construction of the exploitation scenarios was verified in the context of functioning of the technical network system - exploited water supply system ${ }^{1}$. For this purpose, based on the data sets resulting from the activities of the maintenance department of the analyzed enterprise, and also taking into account the expert workshops, the following assumptions was formulated:

- the starting point for the scenarios was the year 2013, which means, that the tasks were carried out based on the data describ- ing the exploitation policy of the analyzed water supply system in 2013,

- the period of the scenario narrative was set for 20 years, which means, that proposed at the present time, effects and/or consequences of decisions have a chance to develop during this period.

The intended and realized result of the developed procedure should be a set of scenarios specified in qualitative (descriptive) and quantitative (parametric).

The results of the implementation of the A phase of the developed scenario procedure, was:

- a set of the environmental scenario factors arranged by the STEEPVL model (Table 4),

- the main scenario problem, as a conditional formula, actual at the final moment of the assumed period of the developed scenarios: What aspects will have long-term impact on the shape of the exploitation policy realized in relation to the water supply system?

The first stage of the B phase of the scenario procedure, including the structural analysis, was carried out with the use of the MICMAC program - one of the components of the specialized software package based on the principle of algebraic logic Boolle'a, developed by M. Godet and experts from the French Computer Innovation Institute 3IE. Prepared matrices of mutual direct and indirect impacts of the environmental scenario factors of the analyzed exploited water supply system, were first processed to the form of graphs (Fig. 6), and then to the maps of the impacts and relationships (Fig. 7).

The structural analysis allowed to extract the three factors, located in the typical area of the key factors (with the highest level of the di-

\begin{tabular}{|c|c|}
\hline Categories & Scenario envirnment factors \\
\hline $\begin{array}{l}\text { S: } \\
\text { Social } \\
\text { factors }\end{array}$ & $\begin{array}{ll}\text { S-1 } & \text { Level of request and consumption of water in the activity area of the enterprise. } \\
\text { S-2 } & \text { Staff potential of the enterprise. } \\
\text { S-3 } & \text { Staff potential of the maintenance department of the enterprise. }\end{array}$ \\
\hline $\begin{array}{l}\text { T: } \\
\text { Technological } \\
\text { factors }\end{array}$ & \begin{tabular}{|ll}
$T-1$ & Level of modernity of the water supply system. \\
$T-2$ & Access to innovative exploitation solutions on the water supply system. \\
$T-3$ & Level of the use of innovative methods and tools in the exploitation of the water supply
\end{tabular} \\
\hline $\begin{array}{l}\text { EC: } \\
\text { Economic } \\
\text { factors }\end{array}$ & $\begin{array}{l}E C-1 \text { Dynamics of changes in the price (cost) of water supply to consumers. } \\
E C-2 \text { Expenditures for development and modernization of the water supply system. } \\
E C-3 \text { Expenditures for activities of the maintenance department. }\end{array}$ \\
\hline $\begin{array}{l}\text { EL: } \\
\text { Ecological } \\
\text { factors }\end{array}$ & $\begin{array}{l}\text { EL-1 Influence of the water supply system on the environment. } \\
E L-2 \text { Impact of exploitation activities for the water supply system on the environment. }\end{array}$ \\
\hline $\begin{array}{l}\text { P: } \\
\text { Political } \\
\text { factors }\end{array}$ & $\begin{array}{ll}P-1 & \text { State and region policy in the field of water management. } \\
P-2 & \text { Enterprise policy for ensuring supply of water to customers. } \\
P-3 & \text { Importance of the maintenance activity for the enterprise. }\end{array}$ \\
\hline $\begin{array}{l}\text { V: } \\
\text { Value factors }\end{array}$ & $\begin{array}{ll}V-1 & \text { Life style and consumption patterns of the local community. } \\
V-2 & \text { Level of acceptance of maintenance works of the water supply system by the local community. }\end{array}$ \\
\hline $\begin{array}{l}\text { L: } \\
\text { Legal factors }\end{array}$ & $\begin{array}{ll}L-1 & \text { Legislation in the supply of water to consumers. } \\
L-2 & \text { Legal requirements and standards for the exploitation of the water supply system. }\end{array}$ \\
\hline
\end{tabular}
rect and indirect interactions):

Table 4. The list of the scenario environmental factors, as a result of the analysis using the STEEPVL model

\footnotetext{
1 Due to the information range, which may be a strategic value, deliberately omitted the
} name of the analyzed company, which does not affect the value of research. 
a)

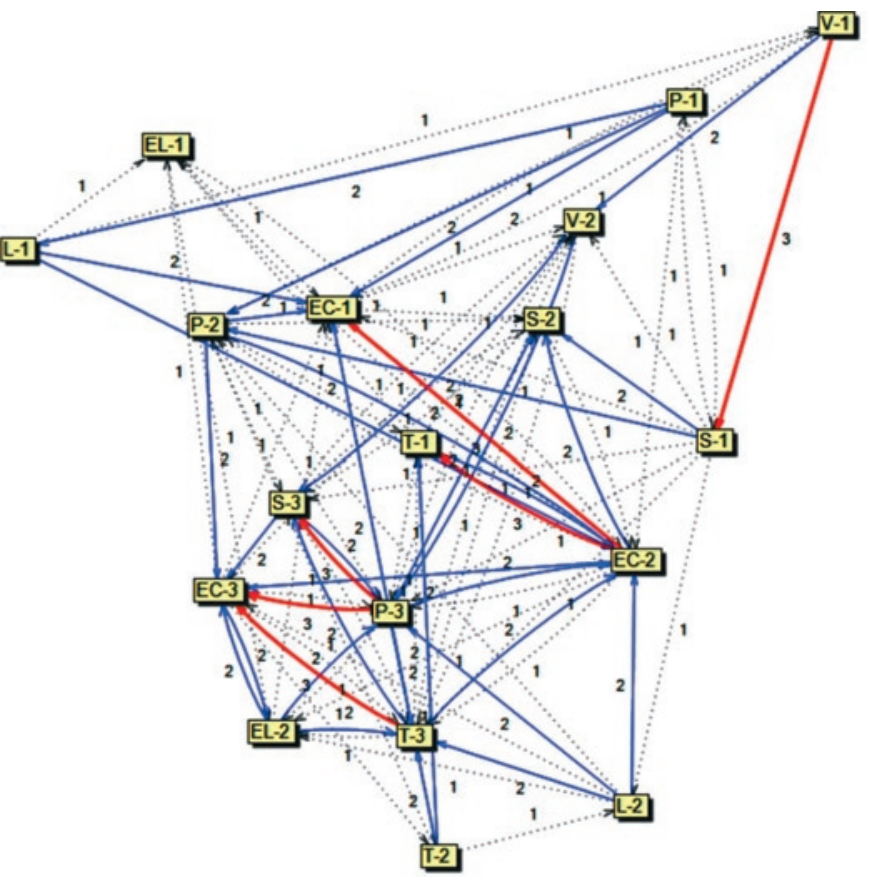

b)

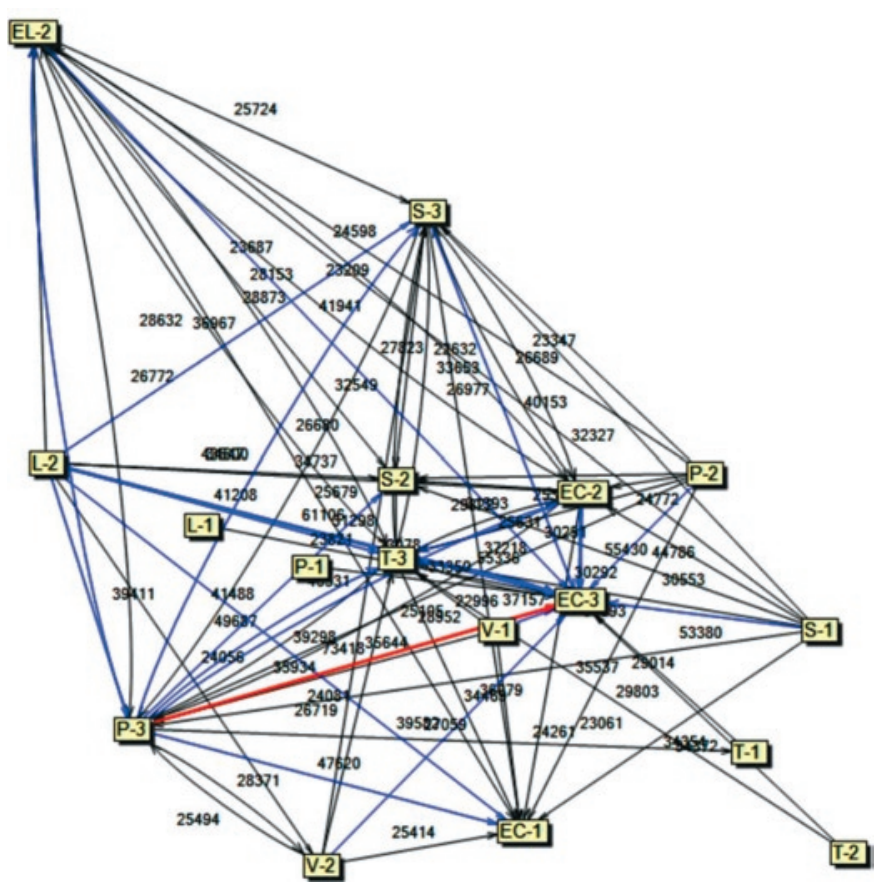

Fig. 6. The graphs of mutual interactions of the scenario environmental features of the analyzed exploited water supply system: a. the graph of direct interactions, b. the graph of indirect interactions

a)

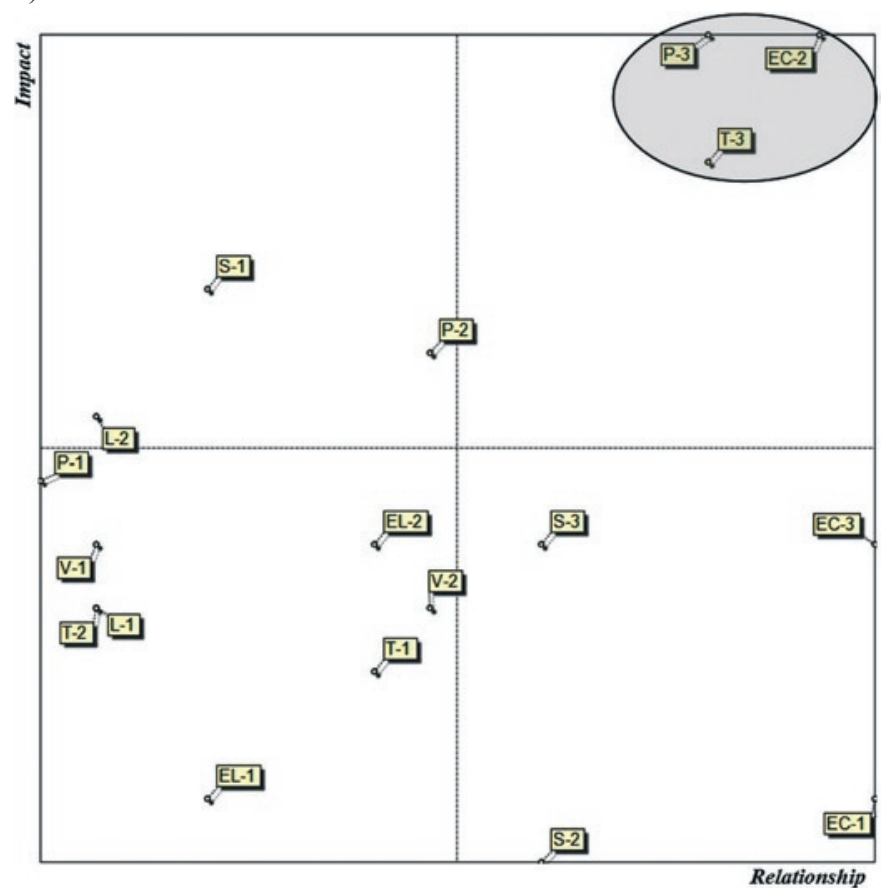

b)

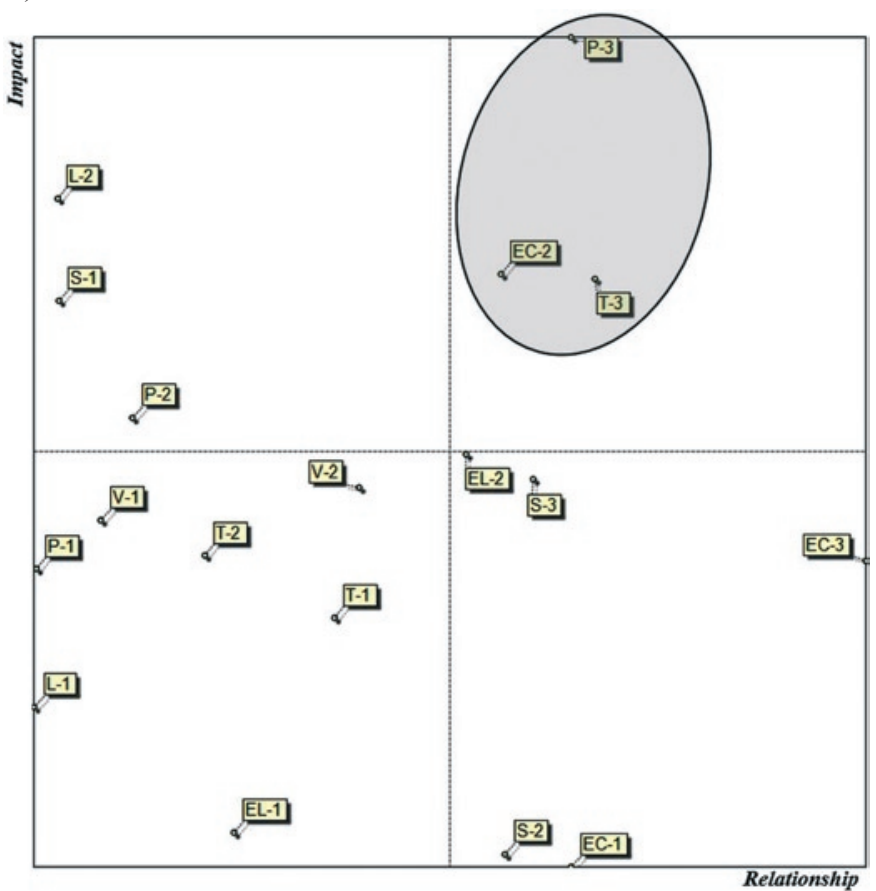

Fig. 7. The maps of mutual interactions of the scenario environmental features of the analyzed exploited water supply system: the map of direct interactions, $b$. the map of indirect interactions

EC-2Expenditures for development and modernization of the water supply system

P-3 Importance of the maintenance activity for the enterprise

T-3 Level of the use of innovative methods and tools in the exploitation of the water supply system

The process of parametric comparison of the key factors, in the context of mutual interactions and the uncertainty level, let to the unambiguous selection of two of them. They were the foundation for construction of the scenarios, determining the directional axes of dis- tribution of influences areas of the particular exploitation future variants (Table 5).

As a basis for scenarios, there was taken the key factors: EC-2 i P-3. It should be noted, that the differences between the interaction/ uncertainty values, for the key factors are low. Simultaneously, the Table 5. The values of interaction/uncertainty for the key factors

\begin{tabular}{|c|c|c|c|}
\hline Factor & $E C-2$ & $P-3$ & $T-3$ \\
\hline Value & $\mathbf{6 , 5}$ & $\mathbf{4 , 5}$ & 4 \\
\hline
\end{tabular}




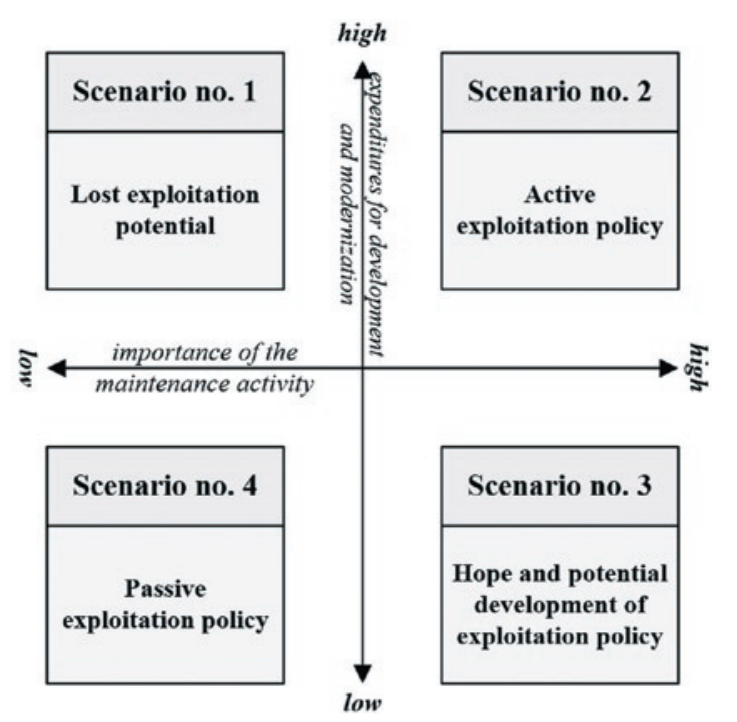

Fig. 8. The layout of the scenarios for the development of the exploitation policy of the analyzed water supply system

values difference between distinguished factors, and other factors ${ }^{2}$, represented by the distance scale of interactions of the direct and indirect influences (Fig. 7), is large enough, that justifies the inclusion of all three factors in the further analysis. There was decided that, due to the importance of T-3 factor in the results of previous studies, it should complement the structure and particular descriptions.

The result of the $\mathrm{C}$ phase of the procedure was the layout of four scenarios for development of the exploitation policy of the analyzed water supply system, as a combination of the extreme values of the analyzed key factors (Fig. 8).

The developed scenarios were described and shown in the symbolic form (Table 6), in the schematic form (Table 7) and in the narrative form.

The $\mathrm{D}$ phase of the scenario procedure consisted in the development of the structure of the maintenance works (Table 8), for four scenarios, in the context of the key features of the exploitation policy.

The developed parametric models of the scenarios (the quantitative structure of the maintenance works), were the basis for the identification of the values of the taxonomic measures (based on the formulas (7)-(11)). They were used to the variant assessment of the exploitation decision-making process. Achieved values of synthetic
Table 6. The symbolic description of the scenarios for the development of the exploitation policy of the analyzed water supply system

\begin{tabular}{||c|c|c|c|c||}
\hline Key factor & $\begin{array}{c}\text { Scenario } \\
\text { no. 1 }\end{array}$ & $\begin{array}{c}\text { Scenario } \\
\text { no. 2 }\end{array}$ & $\begin{array}{c}\text { Scenario } \\
\text { no. 3 }\end{array}$ & $\begin{array}{c}\text { Scenario } \\
\text { no. 4 }\end{array}$ \\
\hline$\underline{\boldsymbol{E C}-\mathbf{2}}$ & $\max$ & $\max$ & $\min$ & $\min$ \\
\hline$\underline{\boldsymbol{P}-\mathbf{3}}$ & $\min$ & $\max$ & $\max$ & $\min$ \\
\hline$\underline{\boldsymbol{T}-3}$ & $\min$ & $\max$ & $\max / \min$ & $\min$ \\
\hline
\end{tabular}

measures and geometric distances were summarized in Table 9. Graphical visualization of the taxonomic measures for each scenario, is shown in Fig. 9.

\section{The use of scenarios in shaping the exploitation decision-making process}

With a set of the scenario models of the developed taxonomic models, feasible become:

- the analytical taxonomic comparative procedure of the exploitation policy of the analyzed water supply system with the scenario models,

- the assessment of the similarity (convergence) of the exploitation policy with the particular scenarios,

- the assessment of the implementation of the exploitation decision-making process, in the context of potential different future variants, represented by the the scenarios.

These tasks were carried out on the basis of prepared taxonomic models, describing the exploitation policy of the analyzed water supply system (in 2013) and the scenarios for the development of the exploitation policy. The results were summarized in tabular form in Table 10 and graphically in Fig. 10.

The presented results can be drawn the following conclusion: the exploitation policy of the analyzed water supply system realized in 2013, showed the highest taxonomic similarity to the scenario no. 3 - Hope and potential development of exploitation policy. This is confirmed by:

- the smallest values of the differences of the determined taxonomic measures for the analyzed exploitation policy and the indicated scenario,

Table 7. The context (schematic) description of the scenarios for the development of the exploitation policy of the analyzed water supply system

\begin{tabular}{|c|c|c|c|c|}
\hline \multirow{2}{*}{$\begin{array}{l}\text { Factor description/ } \\
\text { Scenario name }\end{array}$} & Scenario no. 1 & Scenario no. 2 & Scenario no. 3 & Scenario no. 4 \\
\hline & $\begin{array}{l}\text { Lost exploitation po- } \\
\text { tential: }\end{array}$ & Active exploitation policy: & $\begin{array}{l}\text { Hope and potential develop- } \\
\text { ment of exploitation policy: }\end{array}$ & $\begin{array}{l}\text { Passive exploitation } \\
\text { policy: }\end{array}$ \\
\hline $\begin{array}{l}\text { EC-2 } \\
\text { What is expenditures for } \\
\text { development and moderni- } \\
\text { zation of the water supply } \\
\text { system? }\end{array}$ & $\begin{array}{l}\text { high level of financing } \\
\text { for development and } \\
\text { modernization of water } \\
\text { supply system }\end{array}$ & $\begin{array}{l}\text { high level of financing for } \\
\text { development and mod- } \\
\text { ernization of water supply } \\
\text { system }\end{array}$ & $\begin{array}{l}\text { low or insufficient level of } \\
\text { financing for development } \\
\text { and modernization of water } \\
\text { supply system }\end{array}$ & $\begin{array}{l}\text { low or insufficient level of } \\
\text { financing for development } \\
\text { and modernization of water } \\
\text { supply system }\end{array}$ \\
\hline $\begin{array}{l}\text { W-3 } \\
\text { What is importance of the } \\
\text { maintenance activity for the } \\
\text { enterprise? }\end{array}$ & $\begin{array}{l}\text { model of limited role of } \\
\text { maintenance department } \\
\text { in enterprise }\end{array}$ & $\begin{array}{l}\text { model of high role of main- } \\
\text { tenance department in the } \\
\text { enterprise }\end{array}$ & $\begin{array}{l}\text { model of high role of main- } \\
\text { tenance department in the } \\
\text { enterprise }\end{array}$ & $\begin{array}{l}\text { model of limited role of } \\
\text { maintenance department in } \\
\text { enterprise }\end{array}$ \\
\hline $\begin{array}{l}\text { T-3 } \\
\text { What is level of the use of in- } \\
\text { novative methods and tools in } \\
\text { the exploitation of the water } \\
\text { supply system? }\end{array}$ & $\begin{array}{l}\text { no need and ability to } \\
\text { explore and implement } \\
\text { innovative maintenance } \\
\text { methods and tools }\end{array}$ & $\begin{array}{l}\text { high activity in exploring } \\
\text { and implementing innova- } \\
\text { tive maintenance methods } \\
\text { and tools }\end{array}$ & $\begin{array}{l}\text { high activity in exploring and } \\
\text { implementing innovative } \\
\text { maintenance methods and } \\
\text { tools }\end{array}$ & $\begin{array}{l}\text { no need and ability to } \\
\text { explore and implement } \\
\text { innovative maintenance } \\
\text { methods and tools }\end{array}$ \\
\hline
\end{tabular}

\footnotetext{
2 Other factors are those that were not included in the building scenarios process, as a result of structural analysis.
} 
Table 8. The quantitative structure of the maintenance works for the scenarios for the development of the exploitation policy of the analyzed water supply system

\begin{tabular}{|c|c|c|c|c|c|c|}
\hline \multicolumn{7}{|c|}{ Sceniario no. 1} \\
\hline & \multicolumn{2}{|c|}{ Costs [PLN] } & \multicolumn{2}{|c|}{ Time [hours] } & \multicolumn{2}{|c|}{ Quantity } \\
\hline Inspections & 49341,74 & $5,39 \%$ & 2552 & $5,00 \%$ & 84 & $5,58 \%$ \\
\hline Maintenances & 140826,33 & $15,39 \%$ & 11700 & $22,94 \%$ & 313 & $20,86 \%$ \\
\hline Repairs & 398179,27 & $43,52 \%$ & 15994 & $31,36 \%$ & 742 & $49,49 \%$ \\
\hline Overhauls & 326652,66 & $35,70 \%$ & 20754 & $40,69 \%$ & 361 & $24,07 \%$ \\
\hline Total & 915000,00 & $100,00 \%$ & 51000 & $100,00 \%$ & 1500 & $100,00 \%$ \\
\hline \multicolumn{7}{|l|}{ Sceniario no. 2} \\
\hline & \multicolumn{2}{|c|}{ Costs [PLN] } & \multicolumn{2}{|c|}{ Time [hours] } & \multicolumn{2}{|c|}{ Quantity } \\
\hline Inspections & 113891,40 & $34,51 \%$ & 41219 & $45,05 \%$ & 4122 & $45,05 \%$ \\
\hline Maintenances & 117420,81 & $35,58 \%$ & 30984 & $33,86 \%$ & 3098 & $33,86 \%$ \\
\hline Repairs & 49242,08 & $14,92 \%$ & 7907 & $8,64 \%$ & 791 & $8,64 \%$ \\
\hline Overhauls & 49445,70 & $14,98 \%$ & 11389 & $12,45 \%$ & 1139 & $12,45 \%$ \\
\hline Total & 330000,00 & $100,00 \%$ & 91500 & $100,00 \%$ & 9150 & $100,00 \%$ \\
\hline \multicolumn{7}{|c|}{ Sceniario no. 3} \\
\hline & \multicolumn{2}{|c|}{ Costs [PLN] } & \multicolumn{2}{|c|}{ Time [hours] } & \multicolumn{2}{|c|}{ Quantity } \\
\hline Inspections & 134157,51 & $14,66 \%$ & 37070 & $24,71 \%$ & 3552 & $30,23 \%$ \\
\hline Maintenances & 257967,03 & $28,19 \%$ & 49451 & $32,97 \%$ & 4171 & $35,50 \%$ \\
\hline Repairs & 166749,08 & $18,22 \%$ & 20540 & $13,69 \%$ & 1280 & $10,90 \%$ \\
\hline Overhauls & 356126,37 & $38,92 \%$ & 42940 & $28,63 \%$ & 2746 & $23,37 \%$ \\
\hline Total & 915000,00 & $100,00 \%$ & 150000 & $100,00 \%$ & 11750 & $100,00 \%$ \\
\hline \multicolumn{7}{|c|}{ Sceniario no. 4} \\
\hline & \multicolumn{2}{|c|}{ Costs [PLN] } & \multicolumn{2}{|c|}{ Time [hours] } & \multicolumn{2}{|c|}{ Quantity } \\
\hline Inspections & 70518,21 & $4,70 \%$ & 4669 & $4,26 \%$ & 171 & $4,16 \%$ \\
\hline Maintenances & 246708,68 & $16,45 \%$ & 22289 & $20,35 \%$ & 747 & $18,21 \%$ \\
\hline Repairs & 609943,98 & $40,66 \%$ & 37171 & $33,95 \%$ & 1610 & $39,27 \%$ \\
\hline Overhauls & 572829,13 & $38,19 \%$ & 45371 & $41,43 \%$ & 1573 & $38,36 \%$ \\
\hline Total & 1500000,00 & $100,00 \%$ & 109500 & $100,00 \%$ & 4100 & $100,00 \%$ \\
\hline
\end{tabular}

Table 9. The calculation results of the taxonomic models within the scenarios for the development of the exploitation policy of the analyzed water supply system

\begin{tabular}{|c|c|c|c|c|c|c|c|c|}
\hline \multirow{2}{*}{$\begin{array}{l}\text { Categories of } \\
\text { maintenance } \\
\text { works }\end{array}$} & \multicolumn{2}{|c|}{ Scenario no. 1} & \multicolumn{2}{|c|}{ Scenario no. 2} & \multicolumn{2}{|c|}{ Scenario no. 3} & \multicolumn{2}{|c|}{ Scenario no. 4} \\
\hline & $\begin{array}{l}\text { Synthetic } \\
\text { measure }\end{array}$ & $\begin{array}{l}\text { Geometr. } \\
\text { distance }\end{array}$ & $\begin{array}{l}\text { Synthetic } \\
\text { measure }\end{array}$ & $\begin{array}{l}\text { Geometr. } \\
\text { distance }\end{array}$ & $\begin{array}{l}\text { Synthetic } \\
\text { measure }\end{array}$ & $\begin{array}{l}\text { Geometr. } \\
\text { distance }\end{array}$ & $\begin{array}{l}\text { Synthetic } \\
\text { measure }\end{array}$ & $\begin{array}{l}\text { Geometr. } \\
\text { distance }\end{array}$ \\
\hline Inspections & 0,5723 & 0,5221 & 0,0958 & 1,1984 & 0,1595 & 1,1261 & 0,6203 & 0,6284 \\
\hline Maintenances & 0,2583 & 0,2640 & 0,1050 & 1,1858 & 0,0759 & 1,5399 & 0,2774 & 0,1609 \\
\hline Repairs & 0,1929 & 0,4893 & 0,3200 & 0,5320 & 0,2460 & 0,8757 & 0,2200 & 0,3471 \\
\hline Overhauls & 0,2102 & 0,4199 & 0,2683 & 0,5673 & 0,0780 & 1,5834 & 0,2183 & 0,3503 \\
\hline
\end{tabular}

- the largest uniformity of the differences of the determined taxonomic measures for all considered categories of the maintenance works,

- the smallest median value for the differences of the determined taxonomic measures.

Interpretation of the results confirms the compliance of developed models with the conditions and circumstances of the industrial observation, made by the author, within the maintenance department, that manages the analyzed water supply system. In this regard, it is worth mentioning the following considerations:
- the water supply system was in a period after years of use, which justifies the need to realize the exploitation policy in line with current service requirements of individual technical objects,

- high level of the exploitation culture of the maintenance staff, associated with the policy of searching for support solutions, provide an opportunity for increase the share of quantity and time of preventive maintenance, while keeping costs at the current level, 


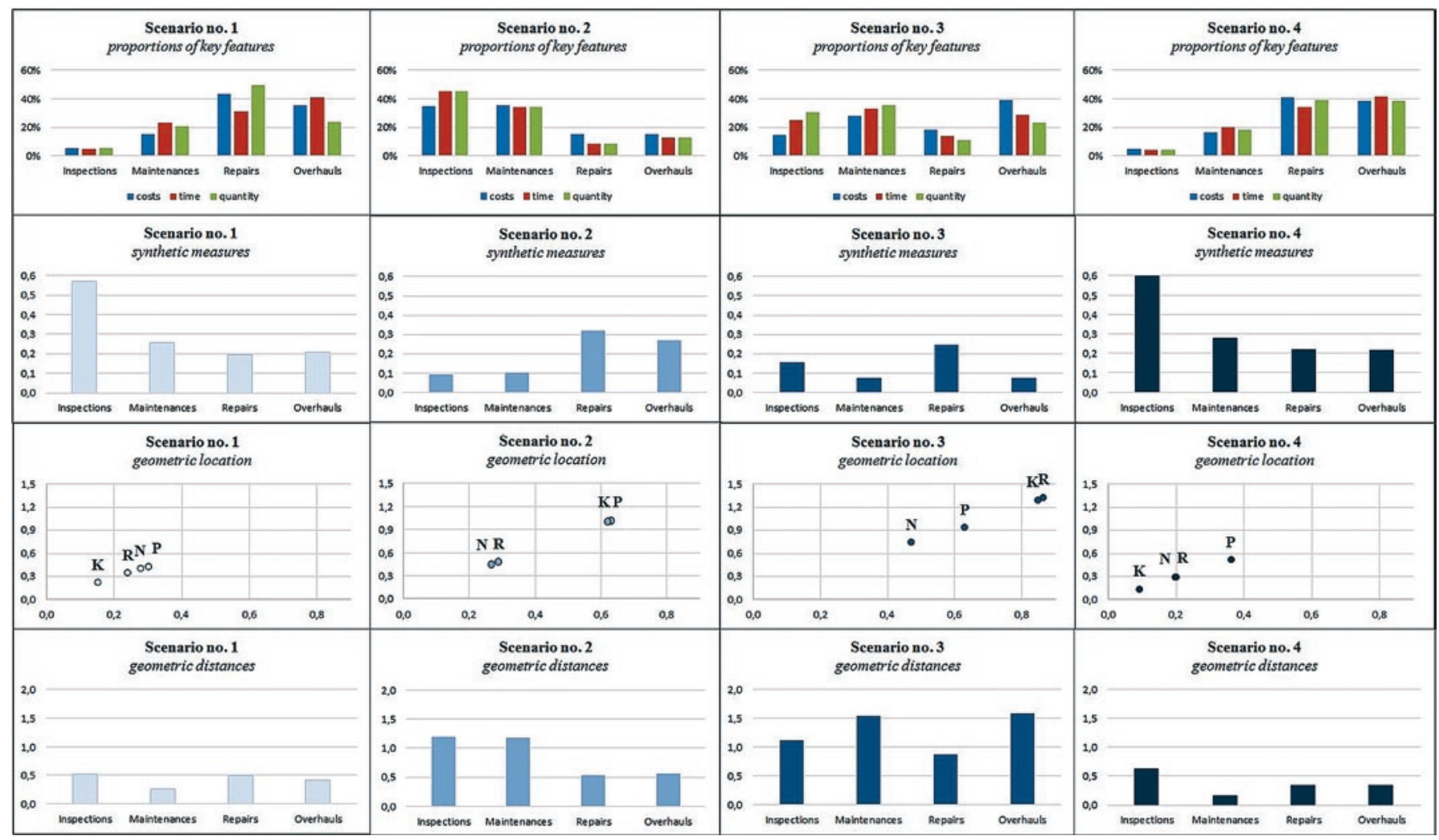

Fig. 9. The graphical presentation of the taxonomic measures of the scenarios for the development of the exploitation policy of the analyzed water supply system

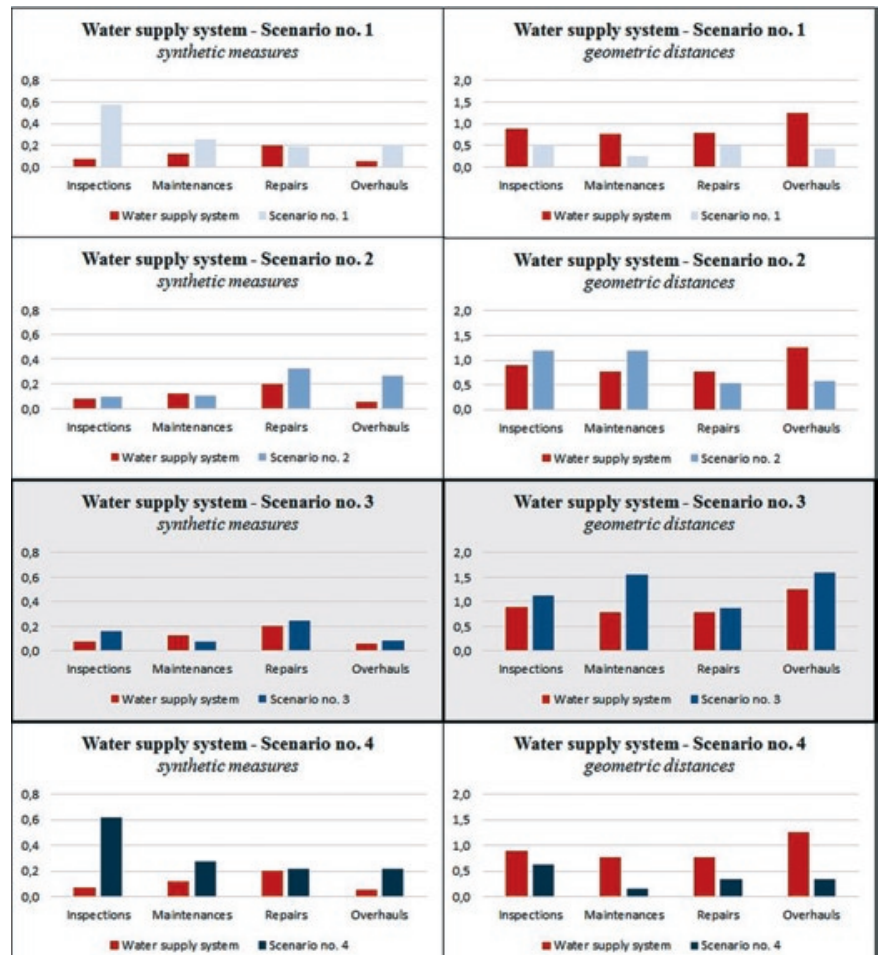

Fig. 10. The graphical comparison of the taxonomic models of the exploitation policy assessment and the scenarios for the development of the exploitation policy of the analyzed water supply system

- the lack of modernization plans of the network in the near term, causes a negative trend for routinization of the maintenance works.
The assessment is temporary, relating to a certain period of time (2013). It is a starting point of the possibilities and advisabilities of introducing changes within the exploitation decision-making process.

In addition to the presented interpretation, scenario shaping of the exploitation decision-making process can proceed in two directions:

1. Monitoring of the exploitation policy, involving the cyclic assessment of the exploitation policy based on the taxonomic models, and then interpretation of the results in the following, predefined, time points. This allows for continuous assessment of direction and level of changes of the similarity (convergence) of the exploitation policy to the particular scenarios, and this in turn, enables to correct principles and guidelines of the exploitation decision-making process.

2. Simulation assessment of changes of the exploitation decision-making process $[15,29]$, consisting in the analysis and interpretation of impact of the features modification on change of the similarity level (convergence) of the exploitation policy with the particular scenarios.

\section{Conclusions}

The results of the research demonstrated the possibility of the assessment and shaping of exploitation future, based on the use of alternative multi-threaded collections of continuous-time or discrete images of reality. Building the scenarios for the development of the exploitation policy of the analyzed water supply system, which was complemented mutual taxonomic assessment, confirmed the need of long-term multifaceted supervision of the exploitation decision making process in industrial environment. The developed methodology of scenario exploitation modeling, adopts a new approach to the exploitation decision-making process, based on resources of assumed and anticipated data on the realization of the exploitation processes.

However, taking into account the objectives, specificity as well as methodological and utilities constraints, it should be noted that: 
Table 10. The result of a comparative analysis of the taxonomic models of the exploitation policy assessment and the scenarios for the development of the exploitation policy of the analyzed water supply system

\begin{tabular}{|c|c|c|c|c|c|c|c|c|c|c|}
\hline \multirow{2}{*}{$\begin{array}{l}\text { Categories of } \\
\text { maintenance } \\
\text { works }\end{array}$} & \multicolumn{2}{|c|}{ Water supply system } & \multicolumn{2}{|c|}{ Scenario no. 1} & \multicolumn{2}{|c|}{ Scenario no. 2} & \multicolumn{2}{|c|}{ Scenario no. 3} & \multicolumn{2}{|c|}{ Scenario no. 4} \\
\hline & $\begin{array}{l}\text { Synth. } \\
\text { meas. }\end{array}$ & Geom. dist. & $\begin{array}{l}\text { Synth. } \\
\text { meas. }\end{array}$ & Geom. dist. & $\begin{array}{l}\text { Synth. } \\
\text { meas. }\end{array}$ & Geom. dist. & $\begin{array}{l}\text { Synth. } \\
\text { meas. }\end{array}$ & Geom. dist. & $\begin{array}{l}\text { Synth. } \\
\text { meas. }\end{array}$ & Geom. dist. \\
\hline Inspections & 0,0423 & 2,0279 & 0,5723 & 0,5221 & 0,0958 & 1,1984 & 0,1595 & 1,1261 & 0,6203 & 0,6284 \\
\hline Maintenances & 0,2147 & 1,0564 & 0,2583 & 0,2640 & 0,1050 & 1,1858 & 0,0759 & 1,5399 & 0,2774 & 0,1609 \\
\hline Repairs & 0,3241 & 0,8362 & 0,1929 & 0,4893 & 0,3200 & 0,5320 & 0,2460 & 0,8757 & 0,2200 & 0,3471 \\
\hline Overhauls & 0,2928 & 0,8631 & 0,2102 & 0,4199 & 0,2683 & 0,5673 & 0,0780 & 1,5834 & 0,2183 & 0,3503 \\
\hline Comparison & & & 0,7874 & 3,0882 & 0,1918 & 1,5590 & 0,5487 & 2,1451 & 0,8194 & 3,2969 \\
\hline Median & & & \multicolumn{2}{|c|}{1,9378} & \multicolumn{2}{|c|}{0,8754} & \multicolumn{2}{|c|}{1,3469} & \multicolumn{2}{|c|}{2,0581} \\
\hline
\end{tabular}

Table 11. The comparison of the specificity of the scenario modeling methods for the classical applications and for the exploitation decision-making process in technical network systems

\begin{tabular}{|l|l|}
\hline Specificity of classical methods of scenario modeling & $\begin{array}{l}\text { Specificity of the exploitation decision-making process in the con- } \\
\text { text of the functioning of technical network systems }\end{array}$ \\
\hline $\begin{array}{l}\text { - individuality of procedures for problems or situations, } \\
\text { - complexity, time-consuming and the necessity of a large commitment of } \\
\text { resources in the development of the models, } \\
\text { identified multifaceted and high detail of analyzed environmental fac- } \\
\text { tors. }\end{array}$ & $\begin{array}{l}\bullet \text { continuous repetitive cyclical nature of realization, } \\
\bullet \text { a narrow range of factors influencing the exploitation decision-making } \\
\text { process in the long term. }\end{array}$ \\
\hline
\end{tabular}

- the modeling methods of future variants can be the basis for the description of equivalent images of exploitation future,

- descriptions of the exploitation future variants are not direct procedures to be followed in the realization of exploitation tasks,

- the modeling methods of future variants is characterized by internal significant level of the decision uncertainty, therefore developed images (scenarios) are dynamic, changing discretely during the time.

An attempt to adapt the classic ways of modeling future variants to the requirements of the exploitation decision-making process, shown the differences, which impede the use of existing typical procedures of the exploitation scenarios within the context of functioning technical network systems. These differences were summarized in Table 11. This causes the need to develop customized scenario solutions.

The research presented in the article was targeted to the technical network systems. However, the prepared methodical, modelled and application solutions does not have any specific restriction by category of a technical system. According to the author, it is possible to implement the scenario shaping the exploitation decision-making process in the context of functioning of industrial installations or production machines and devices. This requires additional work on:

- the development of objects, events and exploitation processes models and their verification in relation to the exploitation policy,

- the adaptation of a set of the exploitation measures used in industrial environment, to the requirements and possibilities of the exploitation decision making process,

- the identification and interpretation of internal and external environment for the exploited industrial (production) technical system, with an additional selection of factors and features, that can be the basis for the scenario modeling.

\section{References}

1. Antosz K, Stadnicka D. Evaluation measures of machine operation effectiveness in large enterprises: study results. Eksploatacja i Niezawodnosc- Maintenance and Reliability 2015; 17 (1): 107-117, https://doi.org/10.17531/ein.2015.1.15.

2. Baran J, Janik A, Ryszko A, Szafraniec M. Making eco-innovation measurable - are we moving towards diversity or uniformity of tools and indicators? Albena: 2nd International Multidisciplinary Scientific Conference on Social Sciences and Arts. SGEM2015; Book 2, Vol. 2: 787 798.

3. Brodny J, Stecuła K, Tutak M. Application of the TPM strategy to analyze the effectiveness of using a set of mining machines. Albena: 16th International Multidisciplinary Scientific GeoConference. SGEM 2016; Book 1: Science and Technologies in Geology, Exploration and Mining: 65-72.

4. Burduk A. Chlebus E. Evaluation of the risk in production systems with a parallel reliability structure. Eksploatacja i Niezawodnosc Maintenance and Reliability 2009; 42 (2): 84-95.

5. Cholewa W, Kaźmierczak J. Data processing and reasoning in technical diagnostics. Warszawa: WNT, 1995.

6. Glenn JC, Gordon J. Future Research Methodology, Version 3.0. 2009, The Millenium Project Publication, 2009.

7. Godet M, Roubelat M. Creating the future: The use and misuse of scenarios. Long Range Planning 1996; 42 (2): 164-171, https://doi. org/10.1016/0024-6301(96)00004-0.

8. Godet M. Creating Futures. Scenario Planning as a Strategic Management Tool - second edition. Paris: Economica Ltd., 2006.

9. Godet M. The Art of Scenarios and Strategic Planning: Tools and Pitfals. Technological Forecasting and Social Change 2000; 65 (1): 3-22, https://doi.org/10.1016/S0040-1625(99)00120-1.

10. Jasiulewicz-Kaczmarek M. Practical Aspects of OEE in Automotive Company - Case Study. Guilin: Proceedings of the 2016 International 
Conference on Management Science and Management Innovation; 2016; Book Series: AEBMR-Advances in Economics Business and Management Research: 213-218, https://doi.org/10.2991/msmi-16.2016.51.

11. Kahane A. The Mount Fleur Scenarios: What will South Africa be like in the year 2002? Deeper News 1996; 7 (1): 1-22.

12. Kahn H, Wiener A.J. A Framework for Speculation on the Next Thirty-Three Years. New York: The Hudson Institute Inc., 1967.

13. Karwot J, Kaźmierczak J, Wyczółkowski R, Paszkowski W, Przystałka W. Smart water in smart city: a case study. Albena: 16th International Multidisciplinary Scientific GeoConference. SGEM 2016; Book 3: Hydrology and water resources: 851-858.

14. Klir GJ, Folger TA. Fuzzy Sets, Uncertainty and Information. New York: Prentice-Hall, Englewood Cliffs, 1988.

15. Kłos S, Patalas-Maliszewska J, Trebuna P. Improving manufacturing processes using simulation methods. Applied Computer Science 2016; 12 (4): 42-53.

16. Koradecka D. Bezpieczeństwo pracy i ergonomia. Warszawa: Centralny Instytut Ochrony Pracy, 1999.

17. Kosicka E, Kozłowski E, Mazurkiewicz D. The use of stationary tests for analysis of monitored residual processes. Eksploatacja i Niezawodnosc - Maintenance and Reliability 2015; 17 (4): 604-609, https://doi.org/10.17531/ein.2015.4.17.

18. Lindgren M, Bandhold H. Scenario Planning. The Link Between Future and Strategy - second edition. New York: Palgrave Macmillan, 2009.

19. Loska A, Moczulski W, Wyczółkowski R, Dąbrowski A.: Integrated system of control and management of exploitation of water supply system. Diagnostyka. 2016; 17(1): 65-74.

20. Loska A. Exploitation assessment of selected technical objects using taxonomic methods. Eksploatacja i Niezawodnosc - Maintenance and Reliability 2013; 15 (1): 1-8.

21. Loska A. Methodology of variant assessment of exploitation policy using numerical taxonomy tools. Management Systems in Production Engineering 2015; 2 (18): 98-104.

22. Loska A. Remarks about modelling of maintenance processess with the use of scenario techniques. Eksploatacja i Niezawodnosc Maintenance and Reliability 2012; 14 (2): 92-98.

23. Loska A. Variant assessment of exploitation policy of selected companies managing technical network systems. Management Systems in Production Engineering 2015; 3(19): 179-188.

24. Mazurkiewicz D. Maintenance of belt conveyors using an expert system based on fuzzy logic. Archives of Civil and Mechanical Engineering 2015; 15 (2): 412-418, https://doi.org/10.1016/j.acme.2014.12.009.

25. Młodak A. Analiza taksonomiczna w statystyce regionalnej. Warszawa: Wydawnictwo Difin, 2006.

26. Moczulski W. Metody pozyskiwania wiedzy dla potrzeb diagnostyki maszyn. Gliwice: Zeszyty Naukowe Politechniki Śląskiej, Wydawnictwo Politechniki Śląskiej, 1997.

27. Nazarko J, Kędzior Z. Uwarunkowania rozwoju nanotechnologii w województwie podlaskim. Wyniki analiz STEEPVL i SWOT. Białystok: Oficyna Wydawnicza Politechniki Białostockiej, 2010.

28. Nazarko J, Wnorowski H, Kononiuk A. Analiza strukturalna czynników rozwoju nanotechnologii w województwie podlaskim. Białystok: Oficyna Wydawnicza Politechniki Białostockiej, 2011.

29. Osak-Sidoruk M, Gola A, Świć A. A method for modelling the flow of objects to be machined in FMS using enterprise dynamics. Applied Computer Science 2016; 12 (2): 42-53.

30. Pahl G, Beitz W. Nauka konstruowania. Warszawa: WNT, 1984.

31. Panek T. Statystyczne metody wielowymiarowej analizy porównawczej. Warszawa: Szkoła Główna Handlowa, 2009.

32. Ringland G. Scenario planning. Managing for the future. Chichester: John Willey \& Sons, Ltd., 2006.

33. Schoemaker P. Scenario planning: A tool for strategic thinking. Sloan Management Review, 1995: 37 (2): 25-40.

34. Van der Heijden, K. Scenarios. The Art of Strategic Conversation. Chichester: John Wiley \& Sons, 1996.

35. Wack P. Scenarios: uncharted waters ahead. Harvard Business Review 1985: 73-89.

36. Wright G, van der Heijden K, Burt G, Bradfield R, Cairns G. Scenario planning interventions in organizations: An analysis of the causes of success and failure. Futures 2008; 40 (3): 218-236, https://doi.org/10.1016/j.futures.2007.08.019.

37. Wyczółkowski R.: Inteligentny system monitorowania sieci wodociągowych. Eksploatacja i Niezawodnosc - Maintenance and Reliability 2008; 37 (1): 33-36.

\author{
Andrzej LOSKA \\ Silesian University of Technology \\ Faculty of Organisation and Management \\ Institute of Production Engineering \\ ul. Roosevelta 26-28, 41-800 Zabrze, Poland \\ E-mail: Andrzej.Loska@polsl.pl
}

